\title{
Cross-Protection of Grapefruit from Decline-Inducing Isolates of Citrus Tristeza Virus
}

\author{
C. A. Powell, R. R. Pelosi, P. A. Rundell, E. Stover, and M. Cohen, University of Florida, IFAS, Indian River Re- \\ search and Education Center, 2199 S. Rock Road, Ft. Pierce 34945-3138
}

\begin{abstract}
Powell, C. A., Pelosi, R. R., Rundell, P. A., Stover, E., and Cohen, M. 1999. Cross-protection of grapefruit from decline-inducing isolates of citrus tristeza virus. Plant Dis. 83:989-991.

The ability of three mild isolates of citrus tristeza virus (CTV) to prevent natural infection of 84 Ruby Red grapefruit on sour orange rootstock by aphid-transmitted, decline-inducing isolates of CTV was assessed by symptoms and verified by enzyme-linked immunosorbent assay (ELISA) after 16 years. Of 21 trees in each of four treatments protected by the DD $102 \mathrm{bb}$, Guettler HS, and DPI 1-12-5-X-E mild CTV isolates, 14, 10, and 14\% were infected by severe isolates (MCA13 monoclonal antibody reactive) compared with $67 \%$ for unprotected control trees. The health of trees protected by the DD $102 \mathrm{bb}$ CTV isolate was significantly better than that of unprotected control trees as measured by decline, tree ratings, and tree height. These data suggest that infection by certain mild isolates of CTV can cross-protect grapefruit trees on sour orange rootstock from decline-inducing isolates of CTV that are prevalent in the Indian River region of Florida.
\end{abstract}

Citrus tristeza closterovirus (CTV) causes economically important disease wherever citrus is grown $(1,3)$. The virus is genetically and biologically diverse and can cause stunting, slow decline, quick decline, stem pitting, or no symptoms depending on the virus isolate, citrus cultivar, rootstock, time of infection, and environmental conditions $(2,4)$. In Florida, two general types of CTV isolates are prevalent: those that cause no detectable symptoms and those that cause stunting and/or decline of citrus on sour orange (Citrus aurantium) or Citrus macrophylla rootstock. CTV isolates that cause stem pitting of the scion variety regardless of the rootstock are not present in commercial citrus in Florida. Therefore, CTV control strategies in Florida have focused on use of tolerant rootstocks to protect against endemic decline isolates and on budwood certification to avoid distribution of any stem pitting isolates that may be introduced by illegal importation of budwood or that may

Corresponding author: C. A. Powell

E-mail: CAPO@gnv.ifas.ufl.edu

This project was funded by USDA cooperative agreement 58-6617-4-018.

Florida Agricultural Experiment Station Journal Series R-066-91.

Accepted for publication 1 July 1999.

Publication no. D-1999-0830-01R

(C) 1999 The American Phytopathological Society already be present in small homeowner plantings.

There are still many productive grapefruit (Citrus paradisi) groves on sour orange rootstock in the Indian River region of Florida that are at high risk from CTVinduced decline. One possible means of maintaining these groves amid declineinducing CTV inoculum is mild strain cross-protection. In 1981, a field experiment to test this hypothesis was initiated at the University of Florida Indian River Research and Education Center at Fort Pierce. The experiment tested the ability of three mild isolates of CTV to protect Valencia sweet orange (Citrus sinensis) and Ruby Red grapefruit on sour orange rootstock from local decline-inducing CTV isolates. The data collected from the sweet orange block indicated that most of these cross-protected trees became superinfected with decline-inducing isolates of CTV within 8 years and declined (7). The data from the adjacent grapefruit block, reported herein, suggest that the same mild isolates prevented superinfection of most of the grapefruit trees for 16 years.

\section{MATERIALS AND METHODS}

Virus isolates and tree propagation. The three mild isolates of CTV-DD 102 bb, Guettler HS, and DPI 1-12-5-X-Ewere described in an earlier report on cross-protection of sweet orange on sour orange rootstock (7). Each of these isolates originated from a surviving sweet orange tree on sour orange rootstock where most of the nearby trees were in decline. Each of the three isolates was initially transferred by grafting from the field tree into several CTV-free Valencia sweet orange trees on sour orange rootstock using three scion bark chips per tree. These inoculum source trees were maintained in an aphid-free greenhouse. The presence of CTV in these trees was confirmed by enzyme-linked immunosorbent assay (ELISA), and the mild phenotype of each of the transferred isolates was verified by indexing on Mexican lime (Citrus aurantifolia) and sweet orange on sour orange indicators.

Budwood from the greenhouse trees containing each of the three mild isolates of CTV was used to inoculate CTV-free Ruby Red grapefruit on sour orange rootstock. As a control, grapefruit were also mock inoculated using buds from a virusfree Valencia sweet orange. The presence or absence of CTV in the grapefruit was verified by ELISA prior to transplanting the trees into the field.

Field plot design. Three trees with each of the four treatments-inoculated with DD 102 bb, Guettler HS, DPI 1-12-5-X-E, or CTV-free buds-were randomized within each of seven plots. Each plot contained 12 trees on two single-row raised beds with six trees on one bed and six on the adjacent bed. The seven plots were planted adjacent to each other in an eastwest direction at the Indian River Research and Education Center at Ft. Pierce, in 1981. The experimental area, therefore, consisted of two rows with 42 trees per row. The experimental area was adjacent to the plots that were used to evaluate these same CTV isolates for cross-protection of sweet orange on sour orange rootstock (7). The Ruby Red grapefruit blocks were irrigated as needed with a microsprinkler system. Pathogens and pests were controlled as needed by application of pesticides according to University of Florida recommendations.

Data collection. In 1997, 16 years after the blocks were planted, trees were evaluated for virus content, decline symptoms, general health, and height. Virus content was evaluated by indirect double antibody sandwich (DAS)-ELISA using monoclonal antibodies that react either with only severe CTV isolates (MCA13) (6) or with all Florida CTV isolates as previously reported (7), except that monoclonal anti- 
body $17 \mathrm{G} 11$ was used as the antibody for general detection of all isolates instead of 3DFl. Each sample consisted of a composite of young flush from three different locations on the tree. Samples were processed with a Tissumizer (Tekmar, Cincinnati, $\mathrm{OH}$ ), as previously described (7). Criteria for judging whether a tree was positive were as previously described (7).

Trees were evaluated for decline in the spring of 1997. A tree was rated as in decline if its foliage was visually thinner than that of healthy trees. Tree ratings were taken at the same time using a 0 to 3 scale, with 0 being no symptoms, 1 being slight decline, 2 being moderate decline, and 3 being severe decline (near death). Thus, trees were first rated on a plus or minus scale for CTV-like symptoms, then rated on the severity of these symptoms. Tree heights $(\mathrm{m})$ were measured in the fall of 1997 with a telescoping measuring rod (Forestry Supplies, Inc., Jackson, MS).

Stem water potential was assessed on five dates (7 and 17 November 1997, 10 April 1998, and 5 and 15 May 1998) using a pressure bomb (Soil Moisture Equipment, Santa Barbara, CA) to determine the effect of mild and severe strains of CTV on plant water relations. Three trees were measured in each of the following categories: (i) trees infected only with each mild isolate of CTV, (ii) trees infected by a severe isolate (MCA13+) that were not yet in decline, and (iii) trees infected by a severe isolate that were in moderate decline. At the start of these measurements, only one tree remained uninfected, and this tree was also assessed. Measured trees were spatially grouped into three blocks, with all CTV categories represented in each block except the uninfected trees. Stem water potential was measured using three intact, fully expanded inner canopy leaves per tree. Leaves were wrapped in plastic, covered with aluminum foil, and left $90 \mathrm{~min}$ while stem and leaf water potentials

Table 1. Incidence of severe isolates of citrus tristeza virus (CTV) and condition of grapefruit trees protected with mild virus isolates after 16 years $^{\mathrm{t}}$

\begin{tabular}{lccccc}
\hline $\begin{array}{l}\text { Protecting } \\
\text { isolate }\end{array}$ & $\begin{array}{c}\text { CTV infection } \\
(\boldsymbol{\%})\end{array}$ & $\begin{array}{c}\text { Severe CTV } \\
\text { infection }^{\mathbf{w}}(\boldsymbol{\%})\end{array}$ & $\begin{array}{c}\text { Decline }^{\mathbf{x}} \\
\mathbf{( \% )}\end{array}$ & Tree rating $^{\mathbf{y}}$ & $\begin{array}{c}\text { Tree height }^{\mathbf{z}} \\
(\mathbf{m})\end{array}$ \\
\hline DD 102 bb & 100 & $14 \mathrm{a}$ & $19 \mathrm{a}$ & $0.69 \mathrm{a}$ & $3.33 \mathrm{a}$ \\
Guettler HS & 100 & $10 \mathrm{a}$ & $29 \mathrm{ab}$ & $0.86 \mathrm{ab}$ & $3.06 \mathrm{ab}$ \\
DPI 1-12-5-X-E & 100 & $14 \mathrm{a}$ & $33 \mathrm{ab}$ & $0.88 \mathrm{ab}$ & $3.00 \mathrm{ab}$ \\
None & 90 & $67 \mathrm{~b}$ & $43 \mathrm{~b}$ & $1.17 \mathrm{~b}$ & $2.83 \mathrm{~b}$ \\
\hline
\end{tabular}

${ }^{t}$ Data are the average of measurements from 21 trees in 7 randomized complete blocks ( 3 trees of each treatment per block). Numbers within a column followed by different letters are significantly different $(P \leq 0.05)$.

u Trees were propagated on sour orange rootstock using buds from Ruby Red grapefruit that had been previously infected with each specific mild isolate of CTV by graft inoculation. Control trees were mock inoculated with buds from uninfected trees.

${ }^{v}$ Percentage of trees positive for CTV using monoclonal antibody $17 \mathrm{G} 11$, which reacts to most Florida CTV isolates.

w Percentage of trees positive for decline isolates of CTV using the decline isolate selective monoclonal antibody MCA13 (6).

${ }^{x}$ Percentage of trees with moderate to severe decline (foliage visibly thinner than healthy trees).

${ }^{\mathrm{y}}$ Rating on a scale of 0 to 3 , with $0=$ no symptoms, $1=$ slight decline, $2=$ moderate decline, and $3=$ severe decline (near death).

${ }^{\mathrm{z}}$ Measured on 23 April 1997. trees being significantly healthier than the control trees. There are at least two reasons for the lack of greater differences in tree health. First, grapefruit trees on sour orange rootstock that became positive for severe CTV may not express symptoms for several years (C. A. Powell, unpublished data) and thus lessen the contrast among treatments, and second, some of the trees were beginning to decline due to causes other than CTV in all treatments. The most notable additional cause of decline was damage from citrus root weevil (Diaprepes abbreviatus).

In an adjacent experiment in which the same mild CTV isolates were used with Valencia sweet orange on sour orange rootstock, cross-protection against natural infection from severe CTV isolates broke down within 8 years (7). This suggests that the ability of the mild isolates of CTV to prevent superinfection with severe isolates was host dependent. The reason cross-protection was successful in grapefruit but failed in sweet orange is not known. Similar differences in mild strain cross-protection between grapefruit and sweet orange have been observed previously (9). These results suggest that close attention must be paid, not only to the protecting isolate and potential challenging isolates, but also to the citrus scion species or cultivar, when developing cross-protection control strategies for CTV.

Within the last year, the experimental area has experienced periodic infestation with the brown citrus aphid (Toxoptera citricida), a supposedly more efficient vector of CTV that has not been present during the 16 years the experiment was conducted. Trees will continue to be monitored for CTV infection and decline to determine the impact of this new vector on cross-protection of grapefruit from severe CTV isolates.

The lack of replication for trees uninfected by CTV prevents development of clear conclusions about CTV influence on water relations, but our results suggest that further investigation is warranted. In addition to affecting tree growth (8), reduced stem water potential results in smaller fruit size (5), which is an important feature in grove economics. If mild CTV strains deleteriously affect water relations, more caution will be needed in recommending widespread infection for cross-protection against severe strains.

\section{LITERATURE CITED}

1. Bar-Joseph, M., Roistacher, C. N., Garnsey, S. M., and Gumpf, D. J. 1981. A review on tristeza, an ongoing threat to citriculture. Proc. Int. Soc. Citric. 1:419-422.

2. Garnsey, S. M., Gumpf, D. J., Roistacher, C. N., Civerolo, E. L., Lee, R. F., Yokomi, R. K., and Bar-Joseph, M. 1987. Toward a standardized evaluation of the biological properties of citrus tristeza virus. Phytophylactica 19:151157.

3. Garnsey, S. M., and Lee, R. F. 1988. Tristeza. Pages 48-50 in: Compendium of Citrus Dis- 
eases. J. O. Whiteside, S. M. Garnsey, and L. W. Timmer, eds. American Phytopathological Society, St. Paul, MN.

4. Miyakawa, T. 1987. Strains of citrus tristeza virus in Japan. Phytophylactica 19:134-144.

5. Noar, A., Klein, I., and Doron, I. 1995. Stem water potential and apple size. J. Am. Soc. Hortic. Sci. 120:577-582.

6. Permar, T. A., Garnsey, S. M., Gumpf, D. J., and Lee, R. F. 1990. A monoclonal antibody that discriminates strains of citrus tristeza virus. Phytopathology 80:224-228.

7. Powell, C. A., Pelosi, R. R., and Cohen, M. 1992. Superinfection of orange trees containing mild isolates of citrus tristeza virus with severe

Florida isolates of citrus tristeza virus. Plant Dis. 76:141-144.

8. Syvertsen, J. P. 1985. Integration of water stress in fruit trees. HortScience 20:10391043.

9. Yokomi, R. K., Garnsey, S. M., Permar, T. A., Lee, R. F., and Youtsey, C. O. 1991. Natural spread of severe citrus tristeza virus isolates in citrus preinfected with mild CTV isolates. Pages 80-92 in: Proc. Conf. Int. Org. Citrus Virol., 11th. R. H. Brlansky, R. F. Lee, and L. W. Timmer, eds. IOCV, Riverside, CA. 